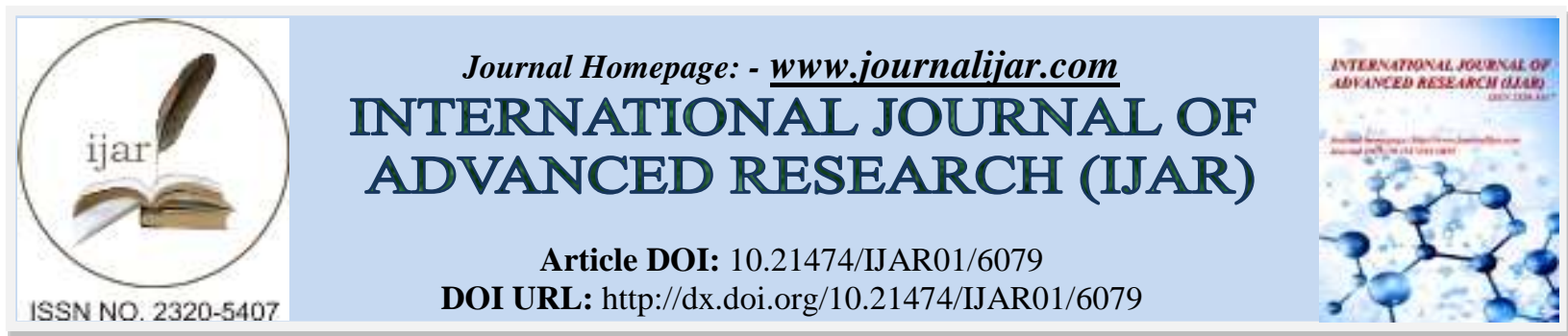

RESEARCH ARTICLE

\title{
THE EFFECT OF ACCEPTANCE OF TECHNOLOGY INNOVATION TOWARDS ACTUAL USAGE THROUGH CONSUMER VALUE ON ONLINE MALL IN SURABAYA, INDONESIA.
}

\author{
*Amelia, SE, MM ${ }^{1}$, Prof. V. Henky Supit, S. E., $\mathrm{Ak}^{2}$ and Dr. Christina Esti Susanti, M. M CPM (AP) ${ }^{3}$. \\ 1. Universitas Katolik Widya Mandala Surabaya. \\ 2. Prof. Universitas Katolik Widya Mandala Surabaya. \\ 3. Universitas Katolik Widya Mandala Surabaya.
}

\section{Manuscript Info}

Manuscript History

Received: 17 October 2017

Final Accepted: 19 November 2017

Published: December 2017

Key words:-

Online mall, Actual Usage, Technology

Acceptance Model, Acceptance of

Technology Innovation and Perceived Value.

\begin{abstract}
In this competitive era, both consumers and producers are trying to develop and ease the purchases process of goods and services. The development of technology creating opportunities for producers to create an easier process for purchasing goods and services for consumers. The purchasing process keeps developing into a more practical online purchase in the midst of busy routine of today's society. The growth and development of online businesses has increased from year to year. However, the increase is also causing the increasing number of online malls that exist today. Thus, it has an impact on the tough competition among existing online malls. This leads to a shorter lifecycle for certain online malls due to the inability to compete and lack of competitive advantage, and ended up being replaced by the better online malls. Therefore, this study aims to find out the factors that affect the actual usage of online mall through several variables, namely, Technology Acceptance Model (perceived usefulness, perceived ease of use), Diffusion of Innovation (compatibility) and perceived value of online mall selection which will be focused on online mall that has the ability to survive the tough competition.

The research method used in this research is quantitative method, and SPSS 22.0 and AMOS 22.0 is used as the data processing software. The type of research is a causal research and a sample of 260 respondents in Surabaya is used.

Ten hypotheses are proposed in this research and the results of the study showed that there are nine significant hypotheses and one hypothesis that is not significant. Perceived ease of use has no significant effect on website actual usage of online consumer in Surabaya. The regression coefficient shows a positive value and this shows a positive correlation but not significant.
\end{abstract}

Copy Right, IJAR, 2017,. All rights reserved.

\section{Introduction:-}

The development of product marketing enters a new phase with the development of technology and information systems (Alagoz and Hekimoglu, 2012; Santouridis and Kyritsi, 2014; Amelia, 2014; Lin, 2007). The development 
is also supported by the growing use of mobile phones and the internet so that the exchange of communication becomes faster and affordable all circles. This is the reason why industry in the world to grow more rapidly and result in increasingly tight competition (Amelia, 2014, Alogoz and Hekimoglu, 2012).

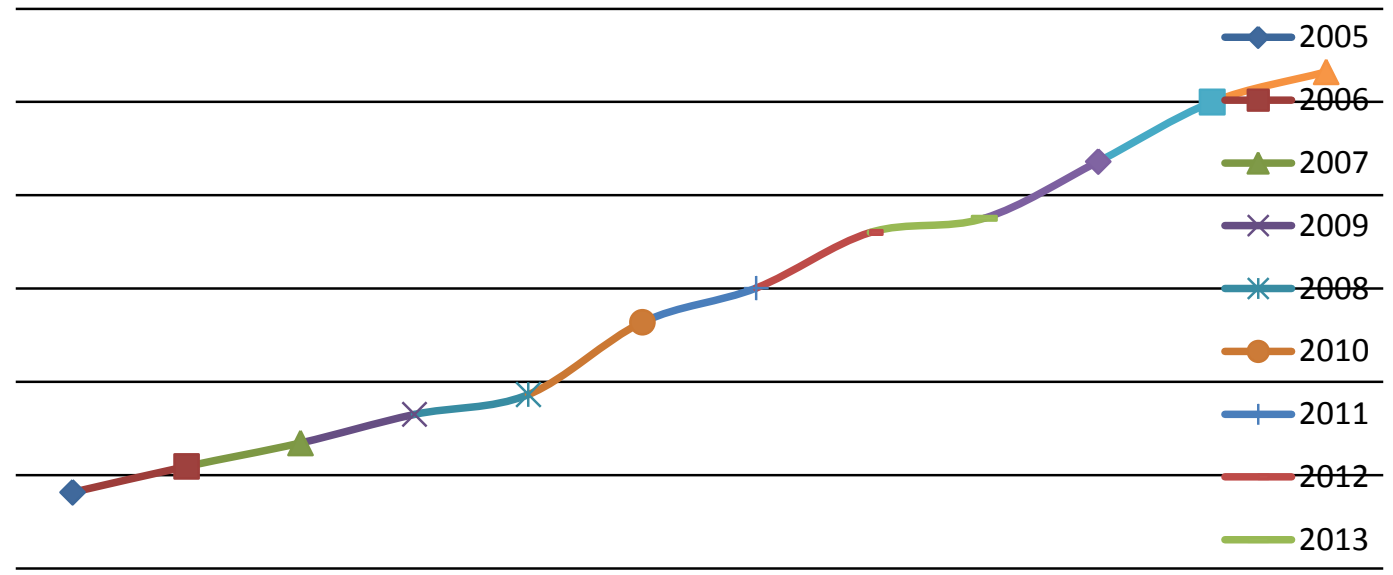

Figure 1.1:- The growth of Internet users in Indonesia in 2005-2016

Source: Internet Live Stats (2016)

The development of the internet that existed to make consumers can obtain data and developments around the world become easily and quickly. In addition, with the growth of internet users will increase the desire of the community to take advantage of existing technology to shop and transact. From Figure 1.1 can be seen a significant increase of internet users in Indonesia from 2005 to 2016. However, the increase in internet users in the Year 2016 will still increase due to data Year 2016 is still the estimated data per July 2016.

\section{USD(Billion)}

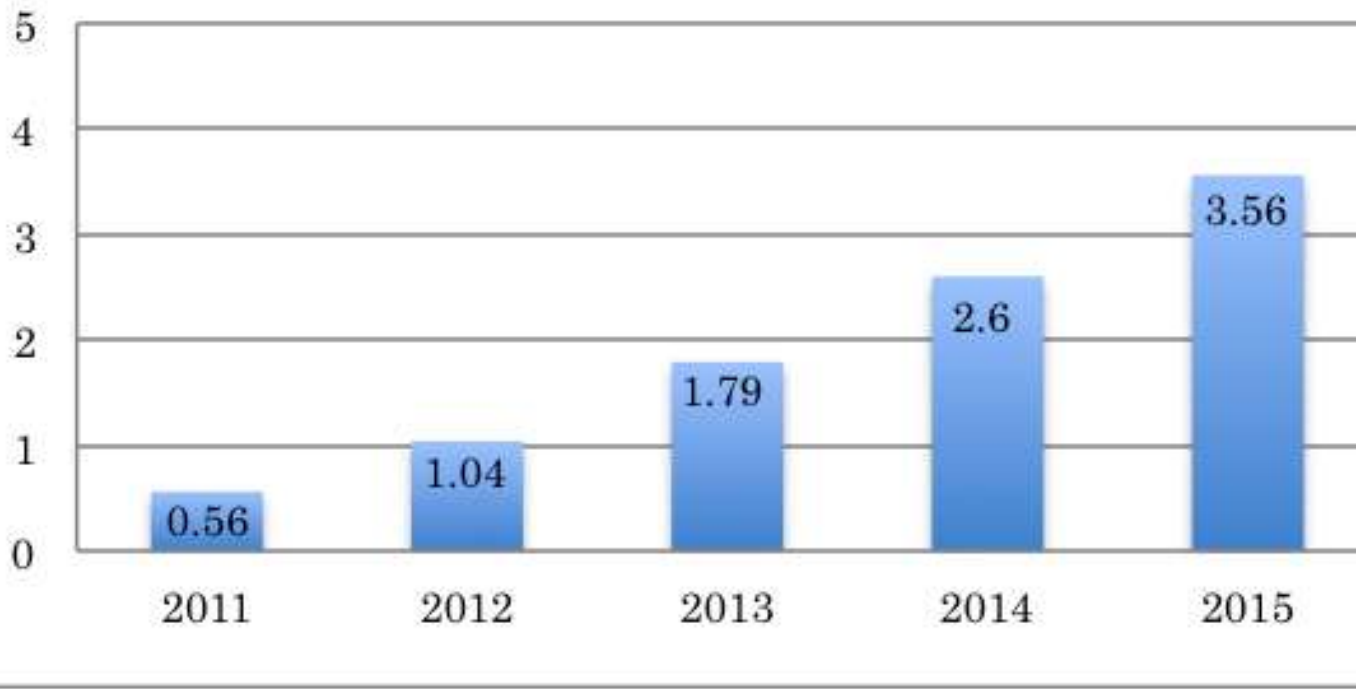

Figure 1.2:- Growth of Sales through E-commerce in Indonesia Year 2011-2015

Source: http://www.emarketservices.com (2016)

The real implication of the high number of internet usage in Indonesia is the increasing number of sellers and buyers who make transactions with internet media (Amelia, 2014). This can be evidenced from Figure 1.2 where seen sales growth that occurred through e-commerce in Indonesia. Growth of sales that occur through e-commerce is also because the online products are cheaper than in stores. This is because the number of discounts given online because 
through the online then the seller can save expenses of sales promotion girl (SPG) or air conditioner (AC) (Wibawa, 2016).

Online shopping becomes a new business development whereby the consumer can get the desired product over the internet and so the seller can reach buyers in the same way (Alagoz and Hekimoglu, 2012; Lian et al., 2008; Lu et al., 2005; Wang et al., 2006). In addition, with online purchases, consumers can choose different types of products compared to traditional shopping (Alagoz and Hekimoglu, 2012; Wang et al., 2006).

This phenomenon of online spending can be seen clearly in the city of Surabaya. As the second city with the largest population in Indonesia (www.kemendagri.go.id, downloaded on August 9, 2017), the need to shop for primary, secondary and tertiary products is enormous. And this shift is seen from the increasingly lonely shopping center in Surabaya. One of the busy shopping center visited by the Surabaya community that is Atom Market Surabaya, but this shopping center also decreased the number of visitors from year to year. One of the reason is the growing of online shopping sites (Hartawan, 2016).

Looking at the phenomenon, the company as an organization must be able to create competitive advantage by using existing information and technology systems such as creating ways to shop online (Ranganathan and Ganapathy, 2002; Amelia, 2014). The reason is because consumers are beginning to realize the advantages of online shopping such as energy saving, easy, competitive pricing, bigger selection rooms and extensive information access (Lin, 2007; Verhoef and Langerak, 2001). However, consumers often do not want to shop online because of the limitations of the web interface in the assessment of retailers rather than direct interaction (Reichheld and Schefter 2000). Therefore, it is important for companies to develop effective websites to facilitate transactions and provide services to consumers as this development is important for understanding consumer decision making regarding online purchases (Lin, 2007).

Consumer decision making in online purchases is related to the Acceptance of Technology Innovation variables. The Acceptance of Technology Innovation is a combination of two main models of Technology Acceptance Model (O'Cass, 2003; Ahn, 2007; Thong, 2002; Alagoz and Hevimoglu, 2012; Amelia, 2011; Amelia, 2012; Santouridis and Kyritsi, 2014; Jayasingh and Eze, 2009; Alagoz and Hekimoglu, 2012; Lin, 2007) and Diffusion of Innovation (Rogers 1995, Lin, 2007; Davis, 1989; Yang et al., 2016; Jayasingh and Eze, 2009; Amelia, 2011; Chen et al., 2009; Corrocher, 2011). Specifically, the Acceptance of Technology Innovation variables are perceived usefulness, perceived ease of use, and compatibility.

The Technology Acceptance Model examines the interests of positive behavior in terms of perceived usefulness and perceived ease of use that will shape attitudes, interests, and ultimately the decision to use the information systems or technologies provided by the company (Wang et al., 2003; Polatoglu and Ekin 2001 ; Moon and Kim, 2001). Davis (1989) defines perceived usefulness as the extent to which a person believes that using a particular system will improve his performance. Research Wang et al. (2003) found that perceived usefulness has an impact on the behavioral desires of the people of Taiwan to adapt the e-banking system significantly. According to Davis (1989), perceived ease of use is the extent to which a person believes that using a particular system will be free from effort. Karahanna et al., (2006) revealed that perceived ease of use is one of the important variables that significantly affect actual usage.

According to Rogers (1995) Diffusion of Innovation can be divided into 5 attributes of relative advantage, compatibility, complexity, trialability, and observability. In this study will be examined attributes compatibility. Moore and Benbasat (1991) define compatibility as an innovation made by a company perceived to be consistent with more value by the user. Research Tornatzky and Klein (1982) explains that compatibility is one of the important characteristics in the innovation needed to be accepted by consumers.

In accordance with the Acceptance of Technology Innovation model the behavior to use is influenced by perceived value and behavioral intention. Cronin et al., (2000) states perceived value as an overall assessment of the utility of a product based on what perceptions are received and what is given. Perceived value is an important part of understanding the field of technology adoption behavior in marketing and information systems (Yu et al., 2015; Kim et al., 2007; Chen and Dubinsky, 2003; Dodds and Monroe, 1985; Dodds et al., 1991; Parasuraman et al., 1985; Wood and Scheer, 1996; Zeithaml, 1988). 
Kim et al., (2007) developed a value-based model for the adoption model of mobile data services from a customer value perspective. Research conducted by Yu et al. (2015) and Kim et al. (2007) produced a significant influence on perceived value of interest in the use of potential customers, therefore it is important to make potential consumers fully perceived value for convincing use of media tablet.

In the end actual usage is important in understanding the context of online shopping. Taylor and Todd (2001) define actual usage as a reflection of feelings of liking or dislike in behavior. Lin Research (2007); Yousafzai and Yani (2012); Moon and Kim (2001); Lu et al., (2009); Amelia (2015); Sambasivan et al., (2010) states that actual usage is the main determinant of online purchases. The online purchase is currently experiencing a major development of online malls (Turban et al., 2015).

Online malls in Indonesia can be regarded as electronic retailing (e-tailing). E-tailing is the intermediate sales between the manufacturer and the consumer through the internet while the e-tailers are the sellers who sell the online retail business (Turban et al., 2015). Online mall is an online shopping where many stores that place catalogs and online malls charge commission fees from the seller based on the sales volume through the online mall (Turban et al., 2015). According to Andi (2006) online mall is a store that is created and operated virtually on the internet where the online mall is almost similar to the real world of mall, a store group in one place or location (Andi, 2006).

Further explanation of the online mall is also explained by Balerina in Loekamto (2012) as a process of purchasing goods / services by consumers to real-time sellers, without waiters and via the internet. Virtual stores change the paradigm of the process of purchasing products / services limited by walls, retailers or malls. This unlimited process is called Business to Consumer (B2C) online shopping. When a businessperson buys from another business it is called online shopping Business to Business (B2B). Both are forms of e-commerce (electronic commerce). Basically the offline mall and online mall are the same. If the mall is offline then the buyer or consumer will come to the mall while the online mall is the buyer or consumer "come to the mall" by opening the website. So in conclusion, the definition of online mall is a means or shops to offer goods and services over the internet, where visitors can see the goods in stores in the mall online. Consumers can see these items in the form of photographs and video.

The explanation from Pratiwi (2013) that the online mall is a digital shopping that can only be used when the device is connected to the Internet network that allows users to connect with shops that sell a variety of needs ranging from clothing, shoes, bags, books, electronic equipment, home appliances and all kinds of human needs can be easily found through shopping site sites.

The growth and development of online business has increased from year to year. However, the increase is causng the increasing number of online malls that exist today. This of course has an impact on the increasingly intense competition from online malls that exist, so the online mall life cycle that is not long survived and replaced by other online malls due to lack of competitive advantage owned (http://www.medanbisnisdaily.com, downloaded on March 1, 2017). Therefore, to be able to know the factors that affect the actual usage of the online mall then the online mall selection must be an online mall that has the ability to survive in the midst of intense competition.

The ability to survive in the midst of intense business competition can be seen from the age of the company. If the company has survived and even expanded in the last 5 years, it shows that the company is successful and staying in business (http://ciputrauceo.net, downloaded on March 1, 2017). Table 1.1 shows the 5 largest online mall markets in Indonesia that have passed the 5 year period since it was first established except the online mall of the new elevania entering 3 years since it was first established.

Table 1.1:- The Big Five E-Commerce Market Share in Indonesia, December 2015

\begin{tabular}{|c|l|l|c|c|}
\hline Number & \multicolumn{1}{|c|}{ E-Commerce } & Country of Origin & \% Market Share & Year Start Operation \\
\hline 1. & Rocket Internet (Lazada) & Jerman & $10.27 \%$ & 2012 \\
\hline 2. & Bukalapak.com & Indonesia & $2.76 \%$ & 2010 \\
\hline 3. & Tokopedia & Indonesia & $1.90 \%$ & 2009 \\
\hline 4. & Amazon.com & U.S. & $1.88 \%$ & 1994 \\
\hline 5. & Elevenia & Indonesia & $1.49 \%$ & 2014 \\
\hline
\end{tabular}

Source: Marketeers Editor (2015) 
Table 1.2:- Characteristics of Online mall and Conformity in Indonesia

\begin{tabular}{|c|c|c|c|c|c|c|}
\hline Number & $\begin{array}{l}\text { Online Mall Characteristic (Turban } \\
\text { et al., 2015; Andi, 2006; Balerina, } \\
\text { 2008; Pratiwi, 2013) }\end{array}$ & Lazada & Bukalapak.com & Tokopedia & Elevenia & Amazon \\
\hline 1. & Many stores place catalogs online & $\sqrt{ }$ & $\sqrt{ }$ & $\sqrt{ }$ & $\sqrt{ }$ & $\sqrt{ }$ \\
\hline 2. & $\begin{array}{l}\text { Online malls charge commission fees } \\
\text { from such sellers based on sales } \\
\text { volume }\end{array}$ & $\sqrt{ }$ & $\sqrt{ }$ & $\sqrt{ }$ & $\sqrt{ }$ & $\sqrt{ }$ \\
\hline 3. & $\begin{array}{l}\text { Shop groups in one place or location } \\
\text { online }\end{array}$ & $\sqrt{ }$ & $\sqrt{ }$ & $\sqrt{ }$ & $\sqrt{ }$ & $\sqrt{ }$ \\
\hline 4. & $\begin{array}{l}\text { Consumers can see the goods sold by } \\
\text { the stores in the form of photographs, } \\
\text { videos, etc. }\end{array}$ & $\sqrt{ }$ & $\sqrt{ }$ & $\sqrt{ }$ & $\sqrt{ }$ & $\sqrt{ }$ \\
\hline 5. & $\begin{array}{l}\text { Digital shopping that can only be } \\
\text { used when the device is connected to } \\
\text { the internet network }\end{array}$ & $\sqrt{ }$ & $\sqrt{ }$ & $\sqrt{ }$ & $\sqrt{ }$ & $\sqrt{ }$ \\
\hline 6. & $\begin{array}{l}\text { Selling various product lines and } \\
\text { categories (clothing, shoes, bags, } \\
\text { books, electronic equipment, home } \\
\text { appliances and all kinds of human } \\
\text { needs) can be easily found through } \\
\text { shopping sites }\end{array}$ & $\sqrt{ }$ & $\sqrt{ }$ & $\sqrt{ }$ & $\sqrt{ }$ & $x$ \\
\hline
\end{tabular}

Source: Turban et al., 2015; Andi, 2006; Balerina, 2008; Pratiwi, 2013; http://www.lazada.co.id; www.bukalapak.com; www.tokopedia.com; http://www.elevenia.co.id/; www.amazon.com (2017)

There are many online malls in Indonesia for example; Lazada, Bukalapak.com, Tokopedia, Elevenia and Amazon. Based on Table 1.1 used in this study are Lazada, Bukalapak.com, Tokopedia, Amazon.com and Elevania that entered into the top 5 e-commerce in Indonesia (Marketeers Editor, 2015). Table 1.2 presents the characteristics of an online mall. Based on the table that entered as an online mall that is Lazada, Bukalapak.com, Tokopedia, and Elevania while Amazon.com is not included in the study because it only sells one product line that is book for delivery to Indonesia, when sending other products then the cost of delivery will be very large making it very unfavorable to consumers (www.amazon.com, downloaded on February 17, 2017).

The result of online mall can be seen as the result of the large market share of each online mall company in Indonesia. Table 1.1 shows that the market share of online mall in Indonesia is quite large in December 2015. Therefore, this study aims to analyze the effect of Acceptance of Technology Innovation variable on Actual Usage and Consumer Value and influence of Consumer Value variable as intervening variable in influencing Actual Usage.

\section{Literature Review:-}

\section{Acceptance of Technology Innovation :-}

Acceptance of Technology Innovation is a combination of Technology Acceptance Model (Davis, 1989) and Diffusion of Innovation (Rogers, 1995). Davis (1989), describes the measurements of the use of technology in everyday life in the TAM model (Technology Acceptance Model). In the TAM model it is further explained about the technology / information systems designed by the company to explain how users / consumers understand and use a technology (Davis, 1989). The variables in the TAM model are perceived usefulness and perceived ease of use in affecting actual usage with attitude and behavioral intention as intervening variable (Davis, 1989).

Diffusion of Innovation (DOI) is one of the important factors in knowing the interest of adopting from the user (Roger, 1962). According to Rogers (1961), Diffusion of Innovation is the process by which an innovation is communicated through certain channels over time to a group of members of the social system. Furthermore, Rogers (1961) explains diffusion is a form of communication that is specific with regard to the dissemination of messages in the form of new ideas. There are five attributes of Diffusion of Innovation: relative advantage, compability, complexity, trialability, and observability. One of the important factors in motivation is that almost every individual in adopting an innovation is to gain social status. For certain innovations such as fashion clothing and social pride, innovation has one advantage of adopting social value (Roger, 1995). 


\section{Technology Acceptance Model:-}

TAM developed from Theory of Reasoned Action or TRA by Ajzen and Fishbein (1980) is the most widely used model in information systems research. According to the Social Science Citation Index (SSCI) report up to Year 2000, this model has been referred by 424 studies and up to 2003 has been referred by 698 studies (Wiyono et al., 2008). TAM theory is considered very influential and is generally used to describe individual acceptance of the use of information technology systems. The use of the Technology Acceptance Model (TAM) in this study is based on the consideration that empirically TAM has been proven to provide an overview of the behavioral aspects of computer users, where many computer users can easily receive information technology because it is in accordance with what it wants (Igbaria et al. 1995).

\section{Perceived Usefulness :-}

TAM proposes two measurable variables for technological acceptance, one of which is perceived usefulness (Jayasingh and Eze, 2009). Davis (1989) defines perceived usefulness as the extent to which a person believes that using a particular system will improve his performance. The definition comes from the definition of the word useful which means it can be used profitably (Davis, 1989). According to Jayasingh and Eze (2009), perceived usefulness explains the user's perception of the extent to which the system will improve user performance. While Ndubisi and Jantan (2003) states that perceived usefulness is a concept related to an assessment of the benefits obtained by an individual or company from the use of technology. Then the hypothesis are:

H1: Perceived usefulness has significant effect to perceived value of consumer of online mall site in Surabaya.

H4: Perceived usefulness has a significant effect on the actual usage of online consumer mall in Surabaya.

H8: Perceived value mediates the effect of perceived usefulness on the actual usage of online consumer mall sites in Surabaya.

\section{Perceived Ease of Use :-}

Other measured variables TAM proposes for technology acceptance are perceived ease of use (Jayasingh and Eze, 2009). According to Davis (1989), perceived ease of use is the extent to which a person believes that using a particular system will be free from effort. Lin (2007) states that perceived ease of use shows the degree to which a Web site is considered easy to understand, learn or operate. Meanwhile, according to Ndubisi and Jantan (2003), perceived ease of use relates to individual assessment of the effort involved in the process of using technology. Based on TAM's theory, Chong et al., (2010) states that perceived ease of use is the extent to which prospective adopters expect newly adopted technologies to be free of effort with respect to transfer and utilization. Then the hypothesis are:

H2: Perceived ease of use has significant effect on perceived value of consumer of online mall site in Surabaya.

H5: Perceived ease of use has significant effect on actual usage of online mall consumer in Surabaya.

H9: Perceived values mediate the effect of perceived ease of use on the actual usage of online consumer mall sites in Surabaya.

\section{Compatibility:-}

Compatibility is one of the attributes of the Diffusion of Innovation that can be used in measuring the behavior of the use of technology or information systems of service provider products (Rogers, 1995; Tornatzky and Klein, 1982; Davis, 1989). According to Moore and Benbasat (1991), compatibility is the degree to which innovation is perceived to be consistent with existing values, needs, and previous experiences of potential adopters. Meanwhile, according to Schiffman and Kanuk (2007, p.486), compatibility is the extent to which potential consumers feel the new product is consistent with their current needs, values and habits. Blackwell et al., (2006, p.548) states another definition of compatibility, ie compatibility refers to the extent to which these new products are consistent with current individual habits, values, needs and experiences of potential past adopters. Then the hypothesis are:

H3: Compatibility significantly affects the perceived value of consumers online mall site in Surabaya.

H6: Compatibility affects the actual usage of consumers online mall site in Surabaya 
H10: Perceived value mediates the effect of compatibility on actual consumer usage of online mall site consumers in Surabaya

\section{Perceived Value:-}

Cronin et al., (2000) states perceived value as an overall assessment of the utility of a product based on what perceptions are received and what is given. Perceived value is defined as the exchange between benefits and sacrifices perceived by the customer from the offered offer (Ulaga and Chacour, 2001; Woodal, 2003 in Milfelner et al., 2009). The perceived value can also be interpreted as the value of the total bid or in other words, the maximum price paid by the customer for a series of economic and non-economic attributes attached to a product (Reddy, 1991 in Johanna, 2006). Slater (1997); Parasuraman (1997) states that perceived value is important in understanding customer behavior, because the customer's perception of value affects purchasing decisions. Then the hypothesis are:

H7: Perceived value affects actual consumer usage of online mall site in Surabaya.

\section{Actual Usage:-}

The use of information technology (IT usage) in this study is expressed by actual usage variables in accordance with the theory of TAM. There are several different definitions of actual usage. According to Moon and Kim (2001), actual usage is the frequency and volume of user self-reported use. While Serenko (2008) defines actual usage as the extent to which an individual hires an interface agent in Serenko (2008) makes another definition of actual usage ie actual usage indicates the true level of agent use given that the use of this system is voluntary.

\section{Research Issue and Methodology:- \\ Research Issue:-}

The research design used is quantitative research. The design of quantitative research is done through questionnaires to respondents in accordance with the criteria specified. The design of quantitative research used is causal research which is explanatory research. Causal research is a study that aims to test the research hypothesis that is determined based on literature review to answer the formulation of research problems (Malhotra, 2007).

\section{Methodology:-}

In this study, the population used is the consumer online mall site in Surabaya. The reason for the selection of research on online consumer mall site in Surabaya is because Surabaya is the second city that has the largest population in Indonesia (www.kemendagri.go.id, downloaded on August 9, 2017) then the need to shop for primary, secondary and tertiary products is very big. And from year to year there is a shift in the method of pemajaan, this is seen from the increasingly lonely shopping center in Surabaya. One of the busy shopping center visited by the Surabaya community that is Atom Market Surabaya, but this shopping center also decreased the number of visitors from year to year. One cause is the growing online shopping sites (Hartawan, 2016). Therefore, using the population of online consumer malls in Surabaya to be interesting to researched.

Sampling technique used is probability sampling, this is because for the sake of generalization. This study uses questionnaires as the main tool in data collection. In this study, the researcher used purposive sampling technique, where the researcher chose the sample based on the assessment on some characteristics of the sample member which was adjusted to the research intention (Kuncoro, 2003).

Sample for conceptual framework use indicator in this research as many as 26 indicators, therefore the minimum number of samples is 130 - 260 respondents, and for this study determined the number of respondents as many as 260 people. Samples were collected from various societies in Surabaya, with the characteristics of respondents are:

1. Men and women who understand well and often use the internet in daily activities

2. Ever buy and use the product at least 1 time directly at least at 2 online mall sites for each online mall in the past year

3. Ever interacted with customer service from online mall sites in the past year

The collection of questionnaires was collected directly by the researchers without using surveyors where the samples were taken evenly throughout Surabaya in East Surabaya, South Surabaya, West Surabaya, North Surabaya and Central Surabaya for 260 respondents. This shows that the sample data taken can be said to represent the people of Surabaya to all areas in Surabaya. 


\section{Findings and Discussion:-}

Findings:-

Descriptive Statistic:-

Characteristics of Respondents by Gender:-

Information on the gender of the respondent who is the user of the online mall is shown in Table 4.1 as follows:

Table 4.1:- Descriptive Data of Gender Respondent

\begin{tabular}{|c|c|c|c|}
\hline Number & Gender & Amount & Percentage (\%) \\
\hline 1. & Man & 103 & 60,6 \\
\hline 2. & Woman & 157 & 100 \\
\hline
\end{tabular}

Source: Results of questionnaire data collection processed, 2017

In Table 4.1, it shows that respondents who fill out questionnaires are mostly done by women, it can be seen from 157 respondents $(60,4 \%)$ of respondents who are online mall site users are women while 103 respondents other $(39,6 \%)$ are men. This indicates that the online mall sites that exist today are more able to attract the attention of users of the female.

\section{Characteristics of Respondents by Age:-}

Information on the age of respondents who are users of the online mall is shown in Table 4.2 as follows:

Table 4.2:- Descriptive Data of Age Respondent

\begin{tabular}{|c|c|c|c|}
\hline Number & Age & Amount & Percentage (\%) \\
\hline 1. & $18-22$ & 58 & 22,3 \\
\hline 2. & $22-35$ & 165 & 63,5 \\
\hline 3. & $35-50$ & 37 & 14,2 \\
\hline 4. & $50-60$ & 0 & 0 \\
\hline 5. & $>60$ & 0 & 0 \\
\hline \multicolumn{2}{|c|}{ Total } & 260 & 100 \\
\hline
\end{tabular}

Sumber: hasil pengumpulan data kuesioner diolah, 2017

From the results in Table 4.2, it can be seen that the characteristics of respondents by age are dominated by 22-35 age groups (165 respondents (63.5\%), followed by 18-22 age groups, 58 the last age that is an online user of the mall and the respondent is the age group 35-50 that is 37 respondents $(14.2 \%)$. This shows that the majority of online mall users are in the age subgroup of generation $\mathrm{X}$ and $\mathrm{Y}$ generation and the last proportion is baby boomer but none of the respondents are from the senior age group.

\section{Characteristics of Respondents Based on Online Malls Frequently Visited:-}

Information about the online mall frequented by respondents who are users of the online mall is shown in Table 4.3 as follows:

Table 4.1:- Descriptive Data Online malls are Frequently Visited

\begin{tabular}{|c|c|c|c|c|}
\hline Number & Online mall & Amount & Percentage (\%) & Real Percentage (\%) \\
\hline 1. & Lazada & 201 & 29,3 & 77,3 \\
\hline 2. & Bukalapak & 164 & 23,9 & 63,1 \\
\hline 3. & Tokopedia & 165 & 24,1 & 63,5 \\
\hline 4. & Elevania & 156 & 22,7 & 60 \\
\hline \multicolumn{2}{|c|}{ Total } & 686 & 100 & \\
\hline
\end{tabular}

Source: Results of questionnaire data collection processed, 2017

From the results of Table 4.3 is seen online mall frequented by respondents, where Lazada is the most visited online mall that is as much as 201 respondents (77.3\%) often visit the online mall. Furthermore, Tokopedia is the second most visited online mall that is as much as 165 respondents $(63.5 \%)$ and not much different from Bukalapak visitors that is 164 respondents (36.1\%). The last position is Elevania with 156 respondents $(60 \%)$ who often visit the online mall. This result also shows that every respondent minimum visit to 2 online mall, this is because respondents have 
been accustomed to using internet media in everyday shopping activity. In addition, these results are also increasingly reinforcing that the four online malls are the leaders of online mall market in Indonesia (Marketeers Editor, 2015) which can be seen from the four online malls are often visited by more than $50 \%$ of respondents in the daily shopping activities.

\section{Initial Model SEM Results:-}

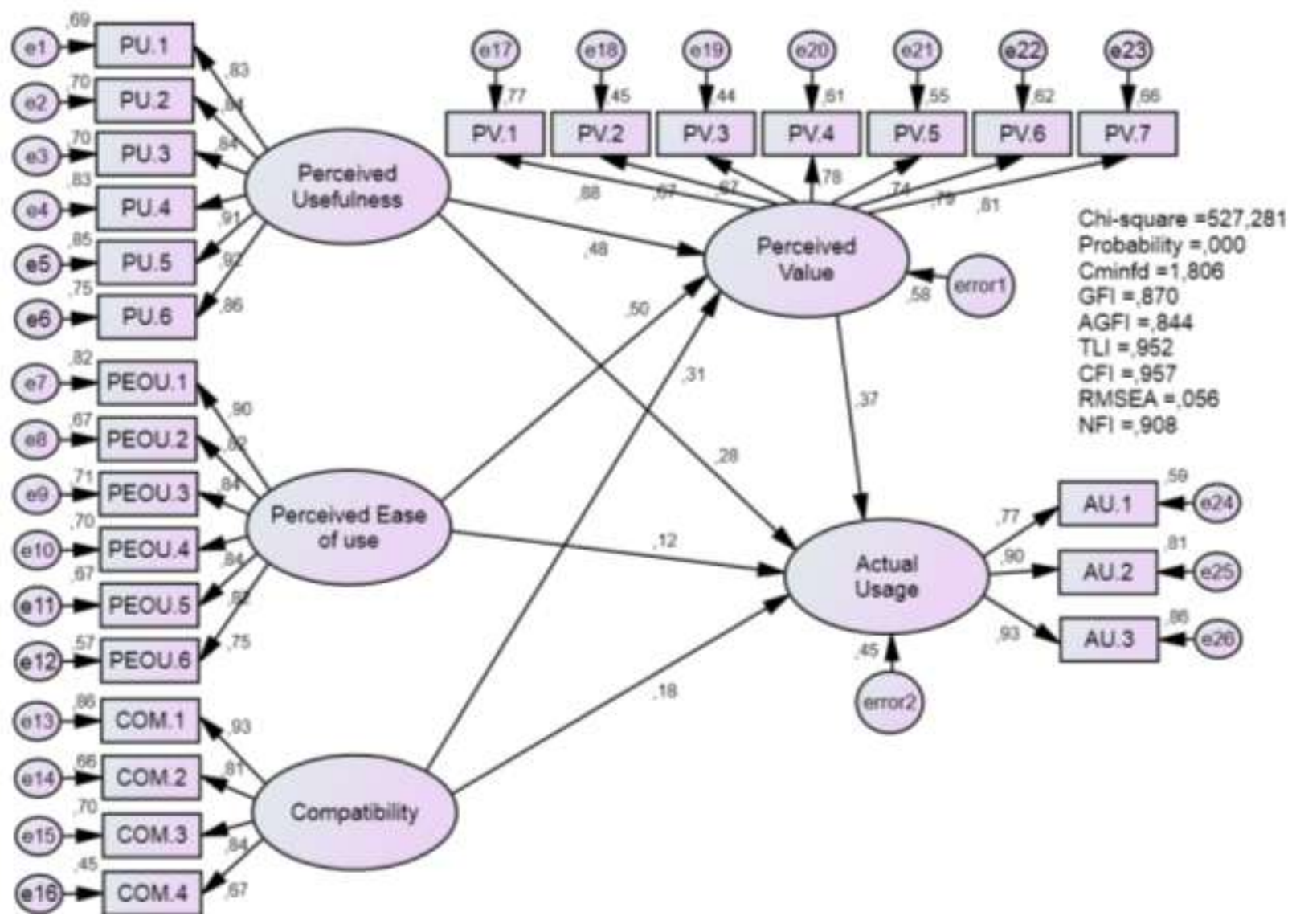

Figure 1:- SEM Model Early Results

Source: AMOS 22, processed

From the above results can be seen that each indicator to each variable has a factor loading (lambda) for each indicator of the variable> 0.40 . This explains that all indicators are able to explain and measure the variables measured and can be used in the next process and together provide unidimensionality for each latent variable.

\section{Structral Model Goodness of Fit :-}

Table 4.4. explain the results of goodness of fit criteria, there are 4 fit criteria (RMSEA, CMIN / DF, TLI, CFI), 3 marginal criteria (GFI, AGFI, and NFI), and 2 unfit / chi-square criteria probability). Thus, the developed structural model is still not good / not fit, then will be modified model with respect to the value of modification indices. 
Table 4.4:- Index of Feasibility Testing of Structural Equation Modeling (SEM)

\begin{tabular}{|c|c|c|c|}
\hline Goodness-of-fit-index & Cut-off Value & Analysis Result & Model Evaluation \\
\hline$\chi^{2}$-chi-square & Small, $\leq 372,4095$ & 527,281 & Non Fit \\
\hline Significant Probability & $\geq 0,05$ & 0,000 & Non Fit \\
\hline RMSEA & $\leq 0,08$ & 0,056 & Fit \\
\hline GFI & $\geq 0,90$ & 0,870 & Marginal Fit \\
\hline AGFI & $\geq 0,90$ & 0,844 & Marginal Fit \\
\hline CMIN/DF & $\leq 2,0$ & 1,806 & Fit \\
\hline TLI & $\geq 0,95$ & 0,952 & Fit \\
\hline CFI & $\geq 0,95$ & 0,957 & Fit \\
\hline NFI & $\geq 0,95$ & 0,908 & Marginal Fit \\
\hline
\end{tabular}

Source: AMOS 22, processed

\section{Discussion:-}

In an effort to find the variables that affect the actual usage of internet banking users in Indonesia, it is necessary to conduct an in-depth search through qualitative study with interview method. Searches conducted starting from May 2017 to June 2017 in the vicinity of East Java.

From Table 1.1 it can be seen that the research model that has been referred to in research is supported from the interview. It can be seen that all customers who use internet banking reflect actual usage and this is also supported by adan behavioral intention. Furthermore, it can be seen that the majority factor which is the reason for using internet banking is perceived usefulness (16 participants) and then for perceived ease of use, perceived credibility and social influence of each 11 participants. And for the next sequence is personal innovativeness and compatibility of 9 and 8 participants.

The results obtained from this qualitative method further strengthen the research model proposed in this study to explain the research objectives of the variables that affect the formation of actual usage of internet banking where the formulation of the problem written is that there is influence perceived usefulness, perceived ease of use, perceived credibility, social influence, personal innovativeness, and compatibility towards actual usage through behavioral intention.

\section{Conclusion, Limitation and Research Extention:-}

Conclusion:-

Respondents' responses to item statements on perceived usefulness variables as measured by the use of information systems products from service providers make shopping activities more enjoyable, increasing the effectiveness of doing activities at any time, increasing the effectiveness in doing activities anywhere, very useful in everyday life , provide facilities to compare products offered, and provide access to information useful for shopping, where each of these indicators have an average mean of 3.83 which means perceived agree by the respondents of internet banking users. In addition to being perceived to be agreed by the respondent, the indicator of perceived usefulness is also valid in measuring the perceived usefulness variable with the rth value greater than the rtable where the rtabel is 0.088 . With a reliability value of 0.897 which is greater than 0.60 then it can be concluded that the perceived usefulness variable reliable in affecting behavioral intention.

Respondents' responses to item statements on perceived ease of use variables measured from Information in relation to information systems products from service providers are easy to obtain, easy to use in shopping, do not take long in shopping activities, easy to understand, how to operate the site which is easy and reliable, where each of these indicators has an average mean of 3.74 which means perceived agree by the respondents of internet banking users. In addition to being perceived to be agreed by the respondent the indicator of perceived ease of use is also declared valid in measuring perceived ease of use variable with value rhitung bigger than rtable where rtabel equal to 0.088 . With a reliability value of 0.869 which is greater than 0.60 then it can be concluded that the perceived ease of use reliable variable in influencing behavioral intention.

Respondents' responses to statement items on perceived credibility variables as measured by user information are kept confidential, transactions are guaranteed, privacy will not be leaked and believe in the security of the banking environment, where each of these indicators has an average mean of 3.75 which means perceived to be agreed by 
respondents from internet banking users. In addition to perceived perceptions by respondents indicator of perceived credibility is also declared valid in measuring variable perceived credibility with value rhitung greater than rtable where $r$ tabel of 0.088 . With a reliability value of 0.825 which is greater than 0.60 then it can be concluded that the perceived credibility variable is reliable in affecting behavioral intention. Top of Form

Respondents' responses to item statements on the variable compatibility measured from the service in accordance with lifestyle, all aspects of daily activities, user personality in the activity and the current hardware (smartphone, etc.), where each of these indicators has average mean of 3.48 which means perceived agree by the respondents of internet banking users. In addition to perceived perceptions by respondents indicator of perceived credibility is also declared valid in measuring variable perceived credibility with value rhitung greater than rtable where rtabel of 0.088 . With the reliability value of 0.875 which is greater than 0.60 then it can be concluded that the perceived credibility variable is reliable in affecting behavioral intention.

Response of respondents to the statement items on personal innovativeness variables as measured from being the first to explore new IT, experimenting, and looking for ways to experiment, where each of these indicators has an average mean of 3.58 which means perceived agree by the respondents from internet banking users. In addition to perceived agree by respondents indicator of personal innovativeness is also declared valid in measuring variable personal innovativeness with value rhitung greater than rtable where rtabel of 0.088 . With the reliability value of 0.793 which is greater than 0.60 then it can be concluded that the personal innovativeness variable is reliable in influencing behavioral intention.

Respondents' responses to items of statements on social influence variables measured from important, influential people affecting behavior and most people around will influence users to use mobile banking, where each of these indicators has an average mean of 3.82 which means perceived agree by the respondents of internet banking users. In addition to perceived agree by the respondent indicator of social influence is also declared valid in measuring social influence variable with value rhitung bigger than rtable where rtabel equal to 0.088 . With a reliability value of 0.878 greater than 0.60 then it can be concluded that the social influence reliable variable in affecting behavioral intention.

Respondents' responses to item statements on behavioral intention variables measured by wanting to know detailed information about fiture, want to increase usage, just want to use internet banking service and want to know the service in internet banking, where each of these indicators have average average mean of 3.60 which means perceived agree by the respondents of internet banking users. In addition to be perceived agree by the respondent indicator of behavioral intention is also declared valid in measuring behavioral intention variable with value rhitung bigger than rtable where rtabel equal to 0,088 . With the reliability value of 0.783 which is greater than 0.60 then it can be concluded that behavioral intention reliable variable in affecting actual usage.

Respondents' response to items of statement on actual usage variables as measured by preferred internet banking services, more often use and perform most transactions using internet banking, where each of these indicators has an average mean of 3.49 which means perceived agree by respondents from internet banking users. In addition to perceived agree by the respondent indicator of actual usage is also declared valid in measuring actual variable usage with value rhitung bigger than rtable where rtabel equal to 0,088 . With a reliability value of 0.845 greater than 0.60 it can be concluded that the actual usage reliable variable for use in this study.

\section{References:-}

1. Agarwal, R. dan Prasad, J. (1998). A conceptual and operational definition of personal innovativeness in the domain of information technology. Information Systems Research Vol. 9 No.2, 204-215.

2. Aggelis, V., 2005. The bible of e-banking. New technologies Publications, Athens

3. Ajzen, I. and Fishbein, M. "Understanding Attitudes and Predicting Social Behavior". Englewood Cliffs, NJ: Prentice-Hall. 1980.

4. Anderson, C., Glassman, M., McAfee, R., Pinelli, T. An investigation of factors affecting how engineers and scientists seek information. Journal of Engineering and Technologi Management (JET-M) 18 (2), 131-155. 2001.

5. Blackwell, R. D., Miniard, P. W., dan Engel, J. F. (2006). Consumer Behavior $10^{\text {th }}$ Edition. Mason: Thomson South-Western.

6. Chong, A. Y.-L., Ooi, K.-B., Lin, B., dan Tan, B.-I. (2010). Online banking adoption: an empirical analysis. International Journal of Bank Marketing Vol. 28 No. 4 , 267-287. 
7. Dabholkar, P., A., Bobbitt, L., Lee, E., -J., 2003. Understanding consumer motivation and behavior related to self-scanning in retailing. Implications for strategy and research on technology-based self-service. International Journal of Service Industry Management, 14, 1, 59-95

8. Davis, F. D. (1989). Perceived Usefulness, Perceived Ease Of Use, And User Acceptance of Information Technology. MIS Quarterly Vol. 13 No.3 , 319-340.

9. Davis, F., D., Bagozzi, R., P., Warshaw, P., R., 1989. User acceptance of computer technology: a comparison of two theoretical models. Management Science, 35, 8, 982-1003

10. Devaraj, S., Kohli, R. Performance impacts of information technology: is actual usage the missing links. Management Science 49 (3), 273-289. 2003.

11. Epper, K., Kutler, J., 1995. Dinosaur remark by Gates sets off technology alarms. The American Banker, January 4, 16

12. Ganesan, S. "Determinants of long-term orientation in buyer-seller relationships"; Journal of Marketing, 58 (2), 1-19. 1994.

13. Ghozali, I. (2004). Model Persamaan Struktural: Konsep dan Aplikasi dengan Program AMOS Ver.5.0. Semarang: Badan Penerbit Universitas Diponegoro.

14. Grandy, T., 1995. Banking in E-Space. The Banker, 145, December, pp74-75

15. Guriting, P., dan Ndubisi, N. O. (2006). Borneo online banking: evaluating customer perceptions and behavioural intention. Management Research News Vol. 29 No. 1/2 , 6-15.

16. Hair, J. R., William, C. B., \& Barry, J. B. (2006). Multivariate Data Analysis $6^{\text {th }}$ Edition. Amerika: Pearson Pentice Hall.

17. Hernandez, J. M., dan Mazzon, J. A. (2007). Adoption of internet banking: proposition and implementation of an integrated methodology approach. International Journal of Bank Marketing Vol. 25 No. 2 , 72-88.

18. Hoyer, W. D., dan MacInnis, D. (2007). Consumer Behavior Fourth Edition. Boston: Houghton Mifflin.

19. Igbaria, M., Tan, M. The consequences of information technology acceptance on subsequent individual performance. Information \& Management 32, 113-121. 1997.

20. Jang, S., Liu, Y., dan Namkung, Y. (2011). Effects of authentic atmospherics in ethnic restaurants: investigating Chinese restaurants. International Journal of Contemporary Hospitality Management Vol. 23 No. 5 , $662-680$.

21. Jani, D., dan Han, H. (2011). Investigating the key factors affecting behavioral intentions Evidence from a fullservice restaurant setting. International Journal of Contemporary Hospitality Management Vol. 23 No. 7 , 10001018.

22. Jayasingh, S., dan Eze, U. C. (2009). An Empirical Analysis of Consumer Behavioral Intention Toward Mobile Coupons in Malaysia. International Journal of Business and Information Vol.4 No.2 , 221-242.

23. Kleijnen, Mirella, Martin Wetzels, dan Ko de Ruyter. (2004). Consumer acceptance of wireless finance. Journal of Financial Services Marketing, Vol 8(3), 206-217.

24. Koenig-Lewis, N., Palmer, A., dan Moll, A. (2010). Predicting young consumers' take up of mobile banking services. International Journal of Bank Marketing Vol. 28 No. 5 , 410-432.

25. Kolodinsky, J., M., Hogart, J., M., Hilgert, M., A., 2004. The adoption of electronic banking technologies by US consumers. The International Journal Of Bank Marketing, 22, 4, 238-259

26. Kuo, Y.-F., dan Yen, S.-N. (2009). Towards an understanding of the behavioral intention to use $3 \mathrm{G}$ mobile value-added services. Computers in Human Behavior 25 , 103-110.

27. Lai, W.-T., dan Chen, C.-F. (2011). Behavioral intentions of public transit passengers-The roles of service quality, perceived value, satisfaction and involvement. Transport Policy18 , 318-325.

28. Lin, H.-F. (2007). Predicting consumer intentions to shop online: An empirical test of competing theories. Electronic Commerce Research and Applications 6, 433-442.

29. Lu, J., Liu, C., Yu, C., dan Wang, K. (2008). Determinants of accepting wireless mobile data services in China. Information and Management Vol.45 No.1, 52-64.

30. Lu, J., Yao, J. E., dan Yu, C.-S. (2005). Personal innovativeness, social influences and adoption of wireless Internet services via mobile technology. Journal of Strategic Information Systems 14, 245-268.

31. Lu, J., Yu, C. S., Liu, C. and Yao, J. E. "Technology acceptance model for wireless Internet"; Internet Research, 13(3), 206-222. 2003.

32. Lu, Y., Zhou, T., dan Wang, B. (2009). Exploring Chinese users' acceptance of instant messaging using the theory of planned behavior, the technology acceptance model, and the flow theory. Computers in Human Behavior 25 , 29-39.

33. Luarn, P., dan Lin, H.-H. (2005). Toward an understanding of the behavioral intention to use mobile banking. Computers in Human Behavior 21, 873-891.

34. Lymperopoulos, C., 1994. Strategic bank marketing. Interbooks Publications, Athens 
35. Molinari, L., dan Blaber, S. (2002). Customer Service and its Effects on Customer Retention and Defection. Midwest Academy of Management 2002 ProceedingsAnnual Conference "Outpacing the Competition: How do Speed, Sustainability, Technology, and Teamwork Lead to the Winner's Circle?”(p. ....). Indianapolis: University of Southern Indiana.

36. Moon, J.-W., dan Kim, Y.-G. (2001). Extending the TAM for a World-Wide-Web context. Information dan Management $38,217-230$.

37. Moore, G. C., dan Benbasat, I. (1991). Development of an Instrument to Measure the Perceptions of Adopting an Information Technology Innovation. Information Research Vol.2 No.3 , 192-222.

38. Namkung, Y. and Jang, S.C. (2007). Does Food Quality Really Matter in Restaurant? Its Impact on Customer Satisfaction and Behavioral Intentions. Journal of Hospitality and Tourism Research Vol. 46, 279.

39. Ndubisi, N. O., dan Jantan, M. (2003). Evaluating IS usage in Malaysian small and medium-sized firms using the technology acceptance model. Logistics Information Management Vol. 16, 440-450.

40. Pollard, C. Exploring continued and discontinued use of IT: a case study of OptionFinder, a group support system. Group Decision and Negotiation 12 (3), 171-193. 2003.

41. Premkumar, G. dan Bhattacherjee, Anol. (2008). Explaining information technology usage:A test of competing models. Omega 36, $64-75$.

42. Puschel, J., Mazzon, J. A., dan Hernandez, J. M. (2010). Mobile banking: proposition of an integrated adoption intention framework. International Journal of Bank Marketing Vol. 28 No. 5 , 389-409.

43. Sadiq-Sohail, M., Shanmugham, B., 2003. E-banking and customer preferences in Malaysia: an empirical investigation. Information Sciences, 150, 3/4, 207-217

44. Sambasivan, M., dan et.al. (2010). User acceptance of a G2B system:a case of electronic procurement system in Malaysia. Internet Research Vol. 20 No. 2 , 169-187.

45. Santoso, S. (2000). Buku Latihan SPSS Statistik Parametrik. PT Elex Media Komputindo.

46. Schierz, P. G., Schilke, O., dan Wirtz, B. W. (2010). Understanding consumer acceptance of mobile payment services: An empirical analysis. Electronic Commerce Research and Applications 9, 209-216.

47. Schiffman, L. G., dan Kanuk, L. L. (2007). Consumer Behavior $9^{\text {th }}$ Edition . New Jersey: Pearson Prentice Hall.

48. Serenko, A. (2008). A model of user adoption of interface agents for email notification. Interacting with Computers $20,461-472$.

49. Shih, Y., -Y., Fang, K., 2006. Effects of network quality attributes on customer adoption intentions of internet banking. Total Quality Management, 17, 1,61-77

50. Shin, D.-H. (2009). Towards an understanding of the consumer acceptance of mobile wallet. Computers in Human Behavior $25,1343-1354$.

51. Taylor, S., Todd, P. Understanding information technologi usage: a test of competing model. .Information System Research 6 (2), 144-176. 1995.

52. Thompson, R.L., C. Higgins dan J. M. Howell. (1991). Personal Computing: Towards a Conceptual Model of Utilization. MIS Quarterly, Vol. 15(1), 125-143

53. Turner, M., Kitchenham, B., Brereton, P., Charters, S., dan Budgen, D. (2010). Does the technology acceptance model predict actual use? A systematic literature review. Information and Software Technology 52, 463-479.

54. Venkatesh, V., Morris, M., Davis, G. B., \& Davis, F. D. (2003). User acceptance of information technology: Toward a unified view. MIS Quarterly Vol. 3, 425-478.

55. Wang, Y., Lo, H. P., \& Hui, Y. V. (2003). The Antecedents of Service Quality and Product Quality and Their Influences on Bank Reputation: Evidence From The Banking Industry in China. Managing Service Quality , 7283.

56. Yang, K. C. C. (2005). Exploring factors affecting the adoption of mobile commerce in Singapore. Telematics dan Informatics, Vol. 22(3), 257-277.

57. Zeithmal, V. A., Bitner, M. J., dan Gremler, D. D. (2009). Service Marketing Integrating Customer Focus Across the Firm Fifth Edition. New York : McGraw-Hill.

58. http://sp2010.bps.go.id/

59. http://tonnymarezco.wordpress.com/2014/04/17/sejarah-internet-banking/

60. www.bi.go.id

61. www.internetworldstats.com/stats3. 